\title{
DIPROTODONTID FOOTPRINTS FROM THE PLIOCENE OF CENTRAL AUSTRALIA
}

\author{
AARON CAMENS ${ }^{*}, 1$ and ROD WELLS ${ }^{2}$ \\ ${ }^{1}$ Department of Earth and Environmental Sciences, University of Adelaide, South Australia 5005, aaron.camens@adelaide.edu.au; \\ ${ }^{2}$ School of Biological Sciences, Faculty of Sciences and Engineering, Flinders University, GPO Box 2100, South Australia 5001
}

\begin{abstract}
The first Pliocene marsupial fossil trackways from Australia are described. The trackways, attributed to Euowenia grata (De Vis) (Diprotodontoidea, Marsupialia), occur in the middle Pliocene Tirari Formation, Warburton River, northern South Australia. The trackways were formed as the animals made their way across a soft claypan. Pad impressions, subsequently infilled by a gypsum-cemented clay, indicate how weight was distributed within the pes.
\end{abstract}

\section{INTRODUCTION}

Analysis of trackways can reveal much about the animal that made them including foot morphology (bone and soft tissue structure), size of the track-maker (height at hip, gleno-acetabular distance), gait (e.g. Thulborn and Wade, 1984; Day et al., 2002), mode of locomotion, and speed of travel (Thulborn, 1990). Additionally trackways can reveal aspects of local ecology including taxonomic diversity, relative abundance of trackmakers (e.g. herbivores versus carnivores), population dynamics (young to adult ratios), behaviour, paleogeography and paleopathology (Lockley, 1986). Alexander (1976) developed an equation for estimating the speed of travel based on observations of trackways of modern mammals. This equation has been applied in numerous ichnological studies of dinosaurs (Thulborn, 1990). Trackways of early tetrapods (e.g. Warren and Wakefield, 1972), dinosaurs (e.g. Thulborn and Wade, 1984; Lockley, 1998) and mammals (e.g. Leakey and Hay, 1979; Lea, 1996; Allen, 1997; Lockley et al., 1999; Ataabadi and Sarjeant, 2000; Mustoe, 2002) have been extensively studied for their paleobiological and biomechanical inferences.

Tertiary and Quaternary fossil mammal trackways are extremely rare in Australia. Those previously recorded consist of Diprotodon optatum Owen (1838) and ?macropodid tracks from Lake Callabonna (Tedford, 1973; Pledge and Tedford, 1990; Wells and Tedford, 1995:111) and hominid and kangaroo trackways from the Willandra Lakes (Webb et al., 2006) and Fowlers Bay (Belperio and Fotheringham, 1990). Diprotodontid, macropodid and vombatid trackways at a site in western Victoria (Australia) are also under investigation by Camens.

In June 2006 the Tedford and Wells expedition to the Lake Eyre Basin resulted in the discovery by R.T. Wells of a series of fossil trackways at a site called Keekalanna Soakage (S 27 ${ }^{\circ} 42.162^{\prime} \mathrm{E} 137^{\circ} 42.539^{\prime}$ and S27 ${ }^{\circ} 42.096^{\prime} \mathrm{E} 137^{\circ} 42.527$ ) (Noolyeana Australia 1:250000 topographic survey) $50 \mathrm{~km} \mathrm{NE}$ of Lake Eyre North (Fig. 1). Here the present day channel of the Warburton River cuts through outcrops of the red-green claystones of the main body of the Pliocene Tirari Formation (Tedford et al., 1992).

Discovery of trackways at Keekalanna Soakage provides direct new evidence on the morphology, gait and paleobiology of the presumed track maker: a diprotodontid marsupial. The iden-

\footnotetext{
*Corresponding author.
}

tity can be assessed by comparison with skeletal remains from this section of the Tirari Formation.

\section{GEOLOGICAL SETTING}

The main body Tirari Formation is composed of laminated red and green clays, representing a lacustrine phase, when the water table in the region was higher than modern levels. Paleomagnetic dating of the Pompapillinna Channels in the upper Tirari Formation suggests that these sediments were deposited about 3.4 Ma under a variable climate with saline lacustrine and freshwater fluvial intervals (Tedford et al., 1992; Tedford et al., 2006). The footprints were found at the base of the laminated lacustrine clays underlying the Pompapillinna Channels; these sediments have been paleomagnetically dated at Keekalanna East, upstream of the foot print site, to approximately 4.8 Ma (Tedford pers. comm., 2007).

\section{MATERIALS AND METHODS}

\section{Trackway Dimensions}

In the field a measuring tape was placed along the centreline of each trackway. Individual footprints were measured and then photographed from above with the measuring tape along side for scale. While on site, each trackway was then plotted on $2 \mathrm{~mm}$ graph paper. The compass orientation of each trackway was also recorded. In the laboratory a photomosaic was assembled for each trackway and another scale plan produced, there being sufficient overlap in the photos to prevent edge distortion (parallax) effects. A small scale representation of each trackway was then plotted on $2 \mathrm{~mm}$ graph paper. Measurements taken from the photomosaic reconstructions did not differ significantly from the actual measurements taken in the field. Stride length, from the median point of a given footprint to the median point of the next print of that foot was, where possible, measured for every stride in each trackway. The degree of variability was then calculated. Trackway width was also measured at regular intervals (by drawing a perpendicular line to that used for stride length from the mid-point of the opposite footprint), along with the dimensions of each footprint, and degree of variability was calculated. In each footprint it was assumed that the pes print completely overprinted that of the manus. A representative print (the fifth trackway from the bank in trackway 1a) was collected for further study, as it was better-preserved than most other prints and most clearly demonstrated the morphology of the pes. 


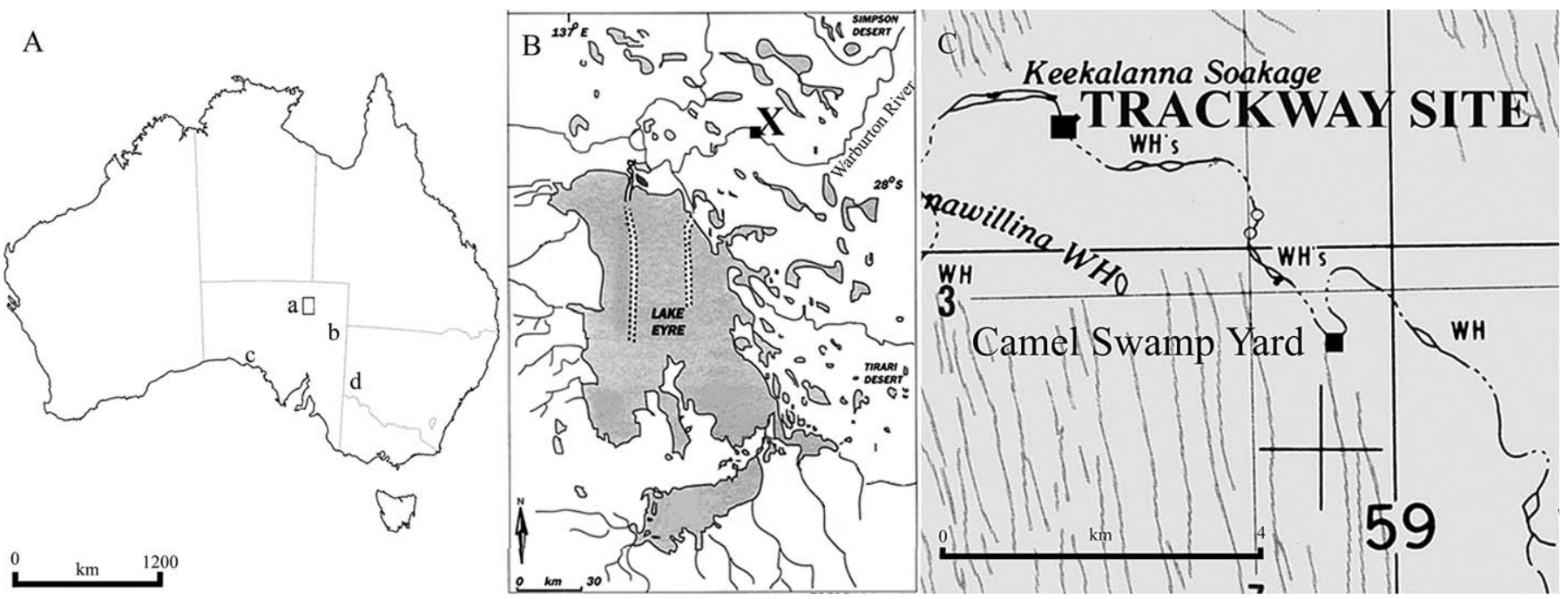

FIGURE 1. A, locations of the known fossil mammal trackway sites in Australia, (a) Warburton River, (b) Lake Callabonna, (c) Fowlers Bay, and (d) Willandra Lakes; $\mathbf{B}$, enlargement of rectangle in $\mathbf{A}$ and (X) the location of the diprotodontid trackway site; $\mathbf{C}$, the location of the diprotodontid trackway site and the two nearby areas where articulated skeletal remains have been found.

\section{Trackway Calculations}

Gleno-acetabular distance (the trunk length, measured from shoulder girdle to acetabulum) was calculated using Haubold's formula " $\mathrm{L}=3 / 4$ stride + distance between footprints of manus and pes" quoted in Stössel (1995:411). Walking speed was estimated based on the formula of Alexander (1976):

$$
\mathrm{V}=0.25 \mathrm{~g}^{0.5} \mathrm{SL}^{1.67} \mathrm{~h}^{-1.17}
$$

where $\mathrm{V}$ is the velocity in $\mathrm{m} / \mathrm{s}$, g represents the acceleration of freefall (9.8), SL refers to Stride Length (m) and h refers to the height of the hip above the ground $(\mathrm{m})$. The height of the hip is estimated by Alexander (1976) to be approximately 4 times the length of the pes. Hip height for analysis of the Warburton trackways was estimated from an articulated hind leg of a diprotodontid found by Wells in 2001 in the main body of the Tirari Formation; the foot of this specimen has a similar overall length to the footprints. Measurements for the Keekalanna Soakage diprotodontid trackways were compared with those taken from the D. optatum trackway at Lake Callabonna by Tedford in 1970 (R. Tedford pers. comm., 2007).

Museum and collection abbreviations include the South Australia Museum (SAM), the Flinders University Palaeontology Collection (FU) and the Queen Victoria Museum and Art Gallery (QVMAG).

\section{RESULTS}

\section{Stratigraphic Provenance}

Trackways were traced laterally into the adjacent southwest bank of the Warburton River channel to ascertain their stratigraphic position. Here it was found that the top of the footprint casts were overlain by laminated, gypsiferous red and green clays of the Tirari Formation (Fig. 2). The footprints are thus clearly intraformational rather than simply impressed into the present day erosional surface (Fig. 3). The footprint casts stood out in relief against the present day erosional surface. These casts consist of a non-laminated gypsum-cemented claystone, which is more resistant to erosion than the surrounding poorly consolidated, laminated claystones and mudstones, and accounts for the preservation of their prints. These thin gypsiferous clays are widely traceable in this part of the Warburton River, representing a shallow saline lake at least $7 \mathrm{~km}$ long (Tedford pers. comm., 2007).

\section{Trackways}

The six trackways (Fig. 4) could be separated into four footprint size groups (Table). However, the variation in footprint size within each trackway made it impossible to determine the exact number of individuals responsible for the multiple trackways. Size group A included trackways $1 \mathrm{a}$ and 4 (foot length $\sim 305 \mathrm{~mm}$, foot width $\sim 205 \mathrm{~mm}$ ), size group B included trackway $1 \mathrm{~b}$ (length $300 \mathrm{~m}$, width $215 \mathrm{~mm}$ ), size group C included trackway 2 (length $320 \mathrm{~mm}$, width $220 \mathrm{~mm}$ ), and size group $\mathrm{D}$ included trackways $3 \mathrm{a}$ and $3 \mathrm{~b}$ (length $\sim 270 \mathrm{~mm}$, width $\sim 175 \mathrm{~mm}$ ).

The trackways were aligned between $040^{\circ}$ and $080^{\circ}$, almost at right angles to the axis of the modern day channel of the Warburton at this point. The six trackways were all found within a $150 \mathrm{~m}$ stretch of the river. The largest separation between different trackways was less than $60 \mathrm{~m}$. The footprints toward the centre of the modern river channel were often broken and displaced, while those closer to the bank were better preserved (Fig. 4). At least one trackway was traceable across the channel to the opposite bank of the river, although the intervening footprints had been lost where erosion had cut deeper into the midsection of the river channel.

In trackway $1 b$, the footprint second closest to the river bank provided evidence of a foot slipping on the clayey mud (Fig. 4, trackway $1 \mathrm{~b}$, elongate print).

\section{Footprints}

Separate manus and pes prints could not be detected due to their almost complete overlap. Most footprints in the trackways were oval, but some of the better defined had a protrusion at one end. Examination of the collected print (Fig. 5) indicated that this protrusion represented the heel of the pes thus allowing determination of the animal's direction of travel.

The size and shape of this footprint compared favourably with the articulated foot skeletons collected from the Tirari Formation at Keekalanna East (FU 2396-2399) and at Camel Swamp Yard (FU 2671) (Fig. 5); both sites were within $6 \mathrm{~km}$ of the fossil trackways in the same stratigraphic position. The collected footprint was $270 \mathrm{~mm}$ long and $145 \mathrm{~mm}$ at its widest, where the impression of the first digit branches, making it a relatively small footprint for the site (see Table). The toe impressions curved medially as in the 


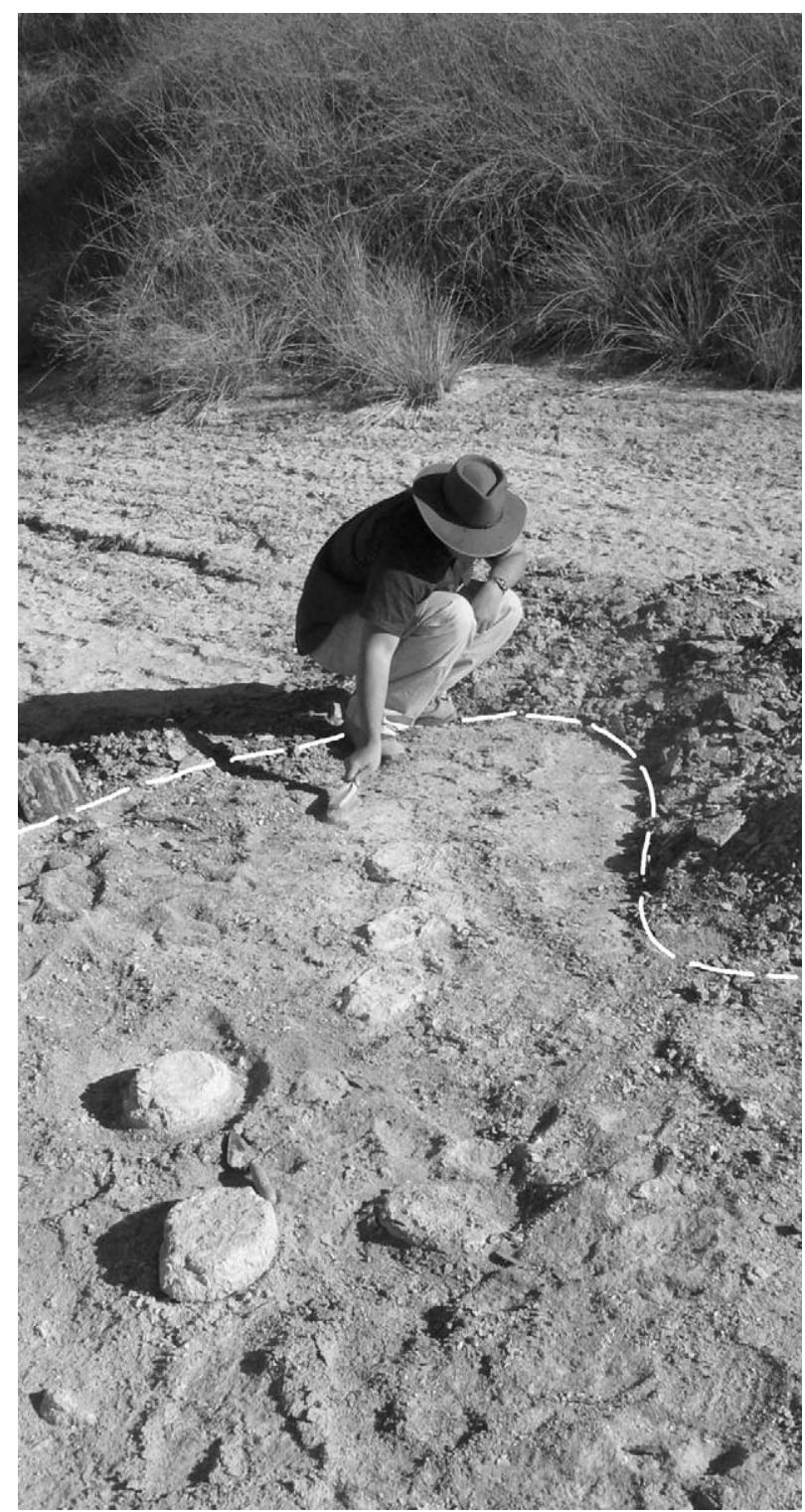

FIGURE 2. Trackways $3 \mathrm{a}$ and $3 \mathrm{~b}$ with modern river bank in background. The dotted line corresponds to that in figure 4 (photo courtesy of T. Worthy).

articulated foot skeleton from Camel Swamp Yard (FU 2671). Footpad impressions suggested a large pad for the medial tarsus near the hallux as in the wombat. Unlike the wombat, the pad near the hallux of this diprotodontid did not connect to the main foot pad positioned below the distal tarsus/metatarsus area. In addition the pad upon which the calcaneum sits was much larger and the digital pads much smaller than in the wombat.

\section{Trackway Analysis}

The stride length for the trackways ranged from 840 to 1170 $\mathrm{mm}$ (average $982 \mathrm{~mm}$ ) and the trackway width ranged from 160 $\mathrm{mm}$ to $360 \mathrm{~mm}$ (average $271 \mathrm{~mm}$ ) (Table). These trackways were approximately a third smaller than the trackways of $D$. optatum from Lake Callabonna, with an average stride length of $1500 \mathrm{~mm}$ and trackway width of $300-500 \mathrm{~mm}$ (Tedford, unpublished data). Average foot length was $295 \mathrm{~mm}$ and average foot width was $202 \mathrm{~mm}$.

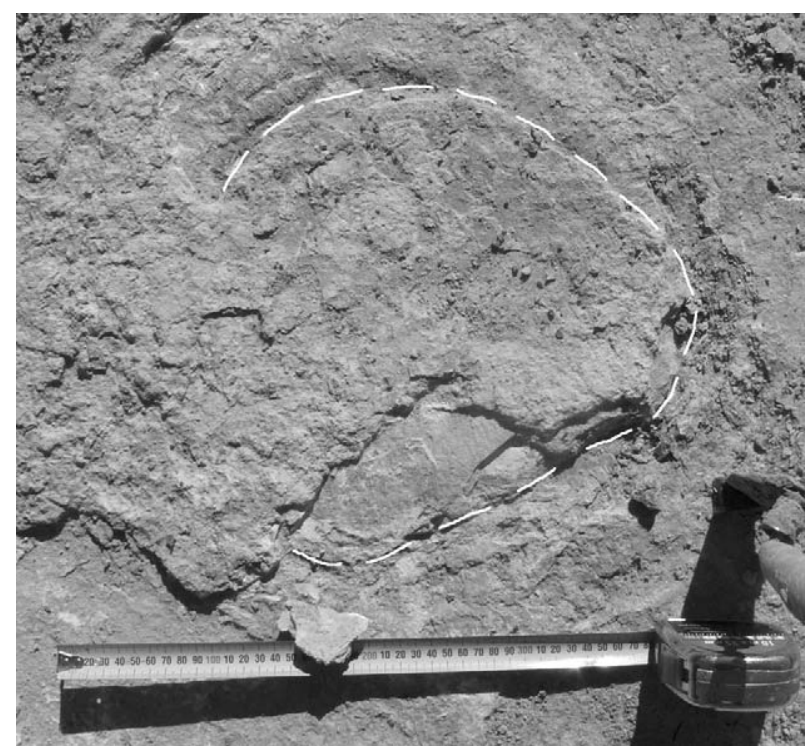

FIGURE 3. A partially excavated footprint demonstrating its stratigraphic position within the main body of the Tirari Formation.

The gleno-acetabular distance (L) for the Keekalanna Soakage diprotodontid was calculated to be $735 \mathrm{~mm}$, compared to the $1125 \mathrm{~mm}$ calculated for the Callabonna D. optatum. The mounted specimen of an articulated D. optatum from Lake Callabonna on display in SAM (P5120-5183) has a gleno-acetabular length of $1530 \mathrm{~mm}$, indicating that the trackways from Lake Callabonna were either made by a smaller individual of the species, or that the calculations may be imprecise.

The estimated walking speed (V) of the Warburton diprotodontid was calculated at $3.5 \mathrm{~km} / \mathrm{h}$.

\section{DISCUSSION}

\section{Identification of the Track Maker}

The only diprotodontid known from the lacustrine clays of the Tirari Formation is Euowenia grata De Vis (1887) (identified from a complete upper dentition). The articulated diprotodontid hind leg with pes (FU 2671) is attributed to E. grata as it occurs in the same stratigraphic horizon. The pes of this specimen matches the size and shape of the footprints. It is therefore suggested that the diprotodontid responsible for the trackways was E. grata.

Several other diprotodontids are known from the Pompapillinna Channels overlying the main body Tirari Formation, including: Nototherium cf. inerme, Euryzygoma dunense and Diprotodon sp. (see Tedford et al., 1986; Tedford and Wells, 1990; Tedford et al., 2006). Species from the Mampuwordu Member underlying the main body Tirari Formation sediments include Meniscolophus mawsoni and Zygomaturus keanei (see Tedford et al., 1992). However all these species are much larger than E. grata and are unlikely to be responsible for the Keekalanna trackways.

\section{Trackway Formation}

The tracks of $D$. optatum at Lake Callabonna were formed as the feet compressed a layer of limy mud, sometimes leaving pad impressions (Pledge and Tedford, 1990; Tedford pers. comm., 2007). Much later deflation of the lake surface left these compressed limestone layers exposed as residuals on very low pedestals of clay. Tedford (1973) noted that, although the foot pad structure was difficult to determine in this form of preservation, 


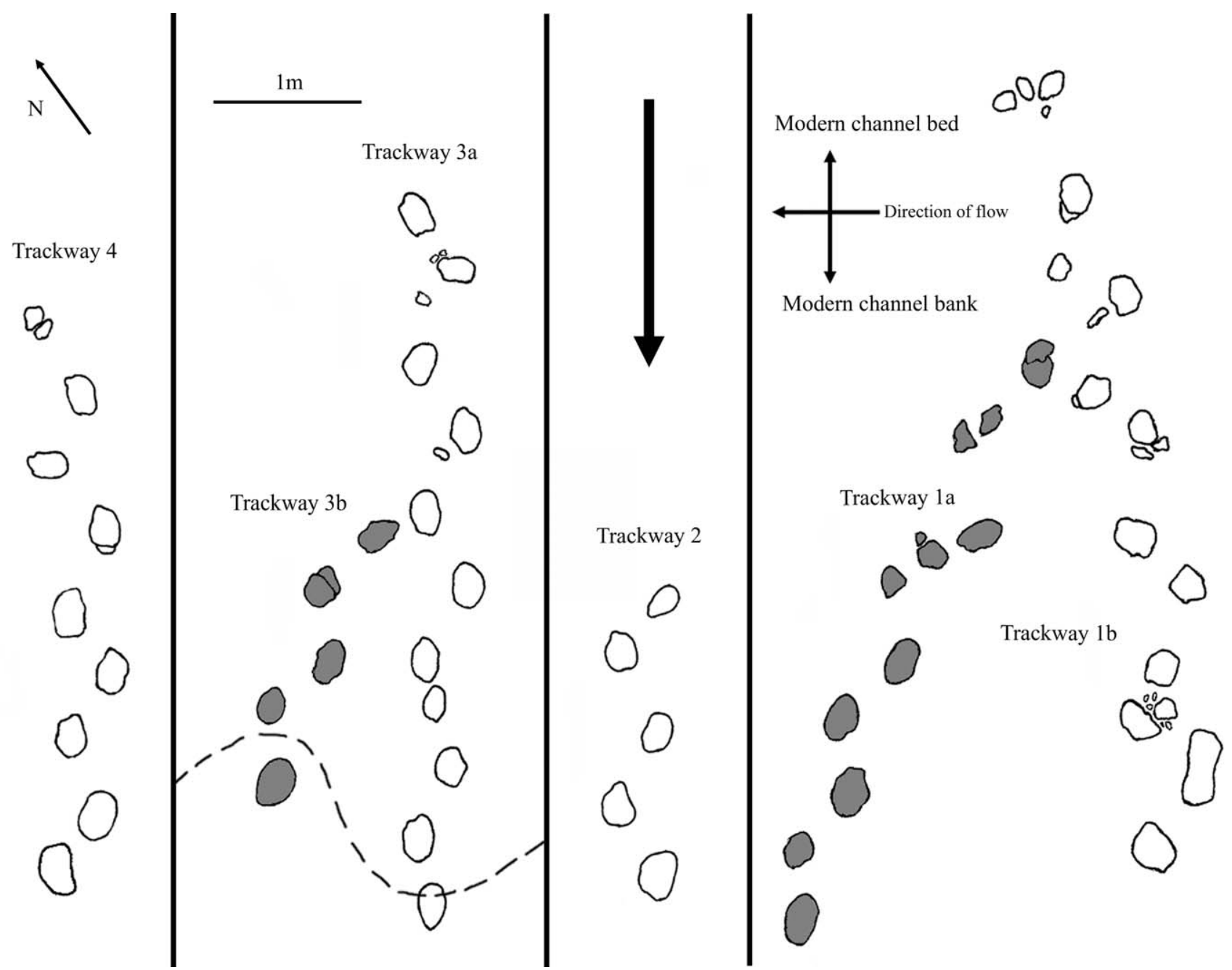

FIGURE 4. Plan view of the six trackways; large arrow indicates direction of travel; distance between each trackway is not to scale; where two trackways intersect shaded prints indicate which prints belong to the intersecting trackway. The dotted line in trackways $3 \mathrm{a}$ and $\mathrm{b}$ corresponds to that marked in Figure 2.

claw marks were visible at the front of the footprints allowing determination of direction of travel. The absence of separate manus and pes prints indicated that the pes almost completely overprinted the manus.

Track preservation at Keekalanna Soakage differs from Lake Callabonna, with the print being preserved on the underside of each pedestal rather than at the top. This suggests that the prints were made in soft clay and were later infilled with sediment which then hardened. The footprints may have been exposed for some time before being infilled as the walls and part of the surface of the print that was collected were partly eroded. This loss of footprint detail could also be due to wet clay slumping at the time of im- printing. The softer sediment surrounding the footprints has been preferentially eroded in the bed of the modern watercourse, leaving natural casts of the tracks as pedestals excavated to varying heights, dependant on their proximity to the centre of the modern river channel. The condition of the sediments at the time of imprinting may also have affected the size of the footprints. The sample collected was one of the better-preserved prints and the dimensions of this print were smaller than the average for the trackways, suggesting that the feet responsible for the tracks were probably smaller than the prints left behind.

The high gypsum component of the pedestals suggests that the filling of the footprints occurred due to wind-blown gypsum that

TABLE. Trackways and footprint size.

\begin{tabular}{lcccc}
\hline Trackway & Stride Length $(\mathrm{m})$ & Trackway Width $(\mathrm{mm})$ & Foot Length $(\mathrm{mm})$ & Foot Width $(\mathrm{mm})$ \\
\hline 1 part a & $0.99 \pm 0.1$ & $265 \pm 59.2$ & $305.2 \pm 29.1$ & $203.5 \pm 27.1$ \\
1 part b & $1.02 \pm 0.13$ & $320 \pm 49.7$ & $300.1 \pm 38.8$ & $213.5 \pm 12.5$ \\
2 & $1.03 \pm 0.09$ & $265 \pm 7.1$ & $26.2 \pm 28.6$ & $219.8 \pm 28.8$ \\
3 part a & $1.01 \pm 0.01$ & $233 \pm 41.8$ & $273.4 \pm 2.5$ & $179.7 \pm 18.1$ \\
3 part b & $0.9 \pm 0.02$ & $245 \pm 7.1$ & $305.6 \pm 31.7$ & 295 \\
4 & $0.94 \pm 0.06$ & $298 \pm 41.1$ & 271.4 & $204.2 \pm 15.9$ \\
Average & 0.98 & 202 & 158 \\
\hline
\end{tabular}



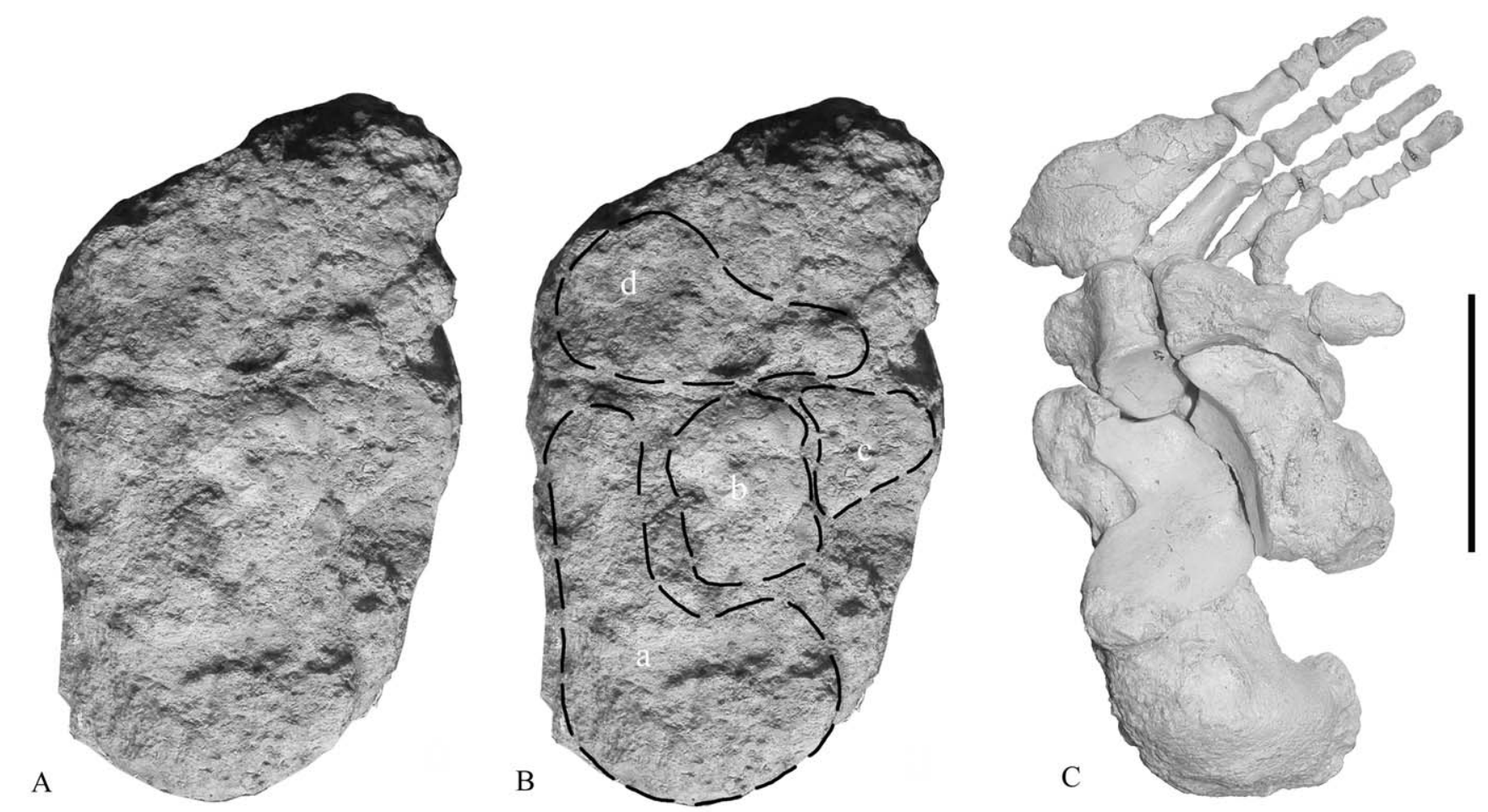

FIGURE 5. A, the collected footprint demonstrating morphology of the pes; $\mathbf{B}$, the interpreted pad morphology showing the calcaneal pad (a), the navicular pad (b), the hallucal pad (c) and the metatarsal pad (d) and $\mathbf{C}$, the articulated pes attributed to E. grata, scale bar equals $10 \mathrm{~cm}$.

had formed on the lake bed during a saline phase. Laporte and Behrensmeyer (1980) suggested that fresh water lakes and rivers are often surrounded by dense vegetation and have a small number of well worn game trails while saltier lakes have low, open vegetation and game trails may not be evident. The spread of the trackways on the Warburton River may therefore indicate that the animals responsible were moving across the border of a saline lake.

Although numerous expeditions to central Australia have been conducted over the last 115 years the number of fossil marsupial trackways discovered remains small. Mammalian trackways from the Plio-Pleistocene of Australia are extremely rare, as is the mode of preservation recorded here. One of the reasons for this paucity of tracks may be that these pedestalled trackways are eroded or re-buried relatively quickly after exposure, meaning that the majority of exposed tracks are rarely detected. This is illustrated by the Callabonna trackways recorded by the Tedford et al. expedition in 1970 of which there was no sign when the area was revisited by the Rich et al. expedition in the early 1990s (T. Rich, pers. comm., 2007).

\section{Footprint Morphology}

The morphology of the foot as determined from the collected print indicates a basic similarity to that of wombats. The major difference between the diprotodontid footprint and those of wombats is that the deepest portion of the print suggests that much more of the weight rested on the tarsus and less on the digits in the former (Fig. 5). This difference in weight distribution in the pes is associated with a reduction in size of the digits in the diprotodontids, while in the wombat well-developed digits are essential for digging. The weight bearing strategies exhibited in the pes of D. optatum and the Keekalanna diprotodontids appear to be characteristic of both the large, derived, Pleisto- cene species as well as at least one graviportal Pliocene member of the Diprotodontine sub-family.

\section{Trackway Analysis}

Speed of Travel-The gleno-acetabular length of the articulated D. optatum skeleton on display in the SAM is 27 percent larger than the length calculated for the individual responsible for the Callabonna trackway. As such the hip height of the latter individual is calculated to be approximately $900 \mathrm{~mm}$ resulting in an estimated speed of $6.3 \mathrm{~km} / \mathrm{h}$. This is much faster than the 3.5 $\mathrm{km} / \mathrm{h}$ determined for the Keekalanna diprotodontid and may reflect the size disparity between the species and/or the result of the latter moving slowly over a slippery clay substrate.

Social Behavior-Although trackways could not be differentiated by size; the footprints indicated only one direction of travel. This suggests a group of up to six individuals all moving in the same direction, implying herd behaviour in the species similar to that proposed by Long and Mackness (1994) for Diprotodon. The occurrence of multiple parallel trackways has previously been used to imply herd behaviour in both dinosaurs and mammals (e.g. Cohen et al., 1993; Day et al., 2002; Lockley et al., 2002).

Biomechanics - The hip height to trackway width ratio for D. optatum is 2.1 (SAM mounted skeleton and Callabonna trackways) and for the Keekalanna diprotodontid is 2.96 (using hind-limb skeleton attributed to E. grata), while the trunk length (gleno-acetabular distance) to hip height ratios are 1.25 and 0.92 respectively. A mounted skeleton of Zygomaturus trilobus (Diprotodontidae) in QVMAG has a hip height to trackway width ratio of approximately 0.92 and a trunk length to hip height ratio of 1.38. This suggests that Zygomaturus had a wider trackway, i.e. walked with the legs spread much further apart 
(as in wombats), while D. optatum and the Keekalanna diprotodontid had the legs positioned closer to vertical beneath the body.

The two different locomotory strategies employed by the diprotodontid sub-families Zygomaturinae and Diprotodontinae may be due to earlier phylogenetic shifts or allometric constraints, but are more likely to indicate habitus differences in derived species. Walking with the legs swinging pendulously under the body (such as in the elephant) is thought to be more energetically efficient when moving long distances than walking with the legs and feet further apart (such as in the wombat). This is because the support role is partially shifted from muscle to bone (Hildebrand, 1988:471) leaving more energy available for locomotion. Narrowing of the trackway and straightening of the limbs such that they swing pendulously under the body serves to increase stride length, resulting in a species being better adapted to move longer distances over relatively firm substrates. Zygomaturus trilobus, with its wider trackway, was mainly restricted to the coastal margins of Australia (Long et al., 2002) and may have foraged around "forest edges, glades and marshes" (Scott, 1915:41) where a more spreadeagled gait would improve stability.

The speed estimated for the Keekalanna diprotodontid is slower than the estimated speed of travel for Diprotodon and that measured in other quadrupedal animals such as elephants (Hutchinson et al., 2003). Assuming that stride frequency was the same the smaller animal would be expected to move slower than the larger animals due to a shorter stride length. It is also feasible that the Keekalanna diprotodontid was taking smaller steps than usual as it walked across the slippery claypan. Shorter stride length relative to hip height would result in an underestimated gleno-acetabular length and hence the hip height to track width ratios for the Keekalanna diprotodontid and D. optatum may be closer than the values given above.

Scaling from the reconstructed SAM skeleton, the Diprotodon responsible for making the trackways at Lake Callabonna is expected to have had a trackway width of approximately 430 $\mathrm{mm}$. This compares favourably with the $300-500 \mathrm{~mm}$ trackway width actually measured at Lake Callabonna (R. Tedford, pers. comm., 2007) and suggests that the displayed D. optatum (SAM P5120-5183) is correctly posed. The skeleton of Z. trilobus in QVMAG is mounted with a very different limb posture to the D. optatum skeleton. Aspects of the morphology of the pectoral and pelvic girdles of $Z$. trilobus indicate correct anatomical positioning of the proximal limb elements and a corresponding wider track than in D. optatum. As there are no known trackways as yet to verify the positioning of the limbs it is possible that the legs may in fact sit further in under the body than is suggested by the reconstruction and hence the ratios expressed above may exaggerate the differences seen between diprotodontines and zygomaturines.

\section{CONCLUSION}

This is the first analysis of (non-human) fossil mammal trackways from Australia. The trackways are unusual in that they are preserved as casts rather than molds. Trackways of up to six individual diprotodontids preserved are attributed to the species Euowenia grata and it is suggested that the animals were travelling at a speed of approximately $3.5 \mathrm{~km} / \mathrm{h}$ as they walked across a slippery claypan. The narrow trackways contribute evidence suggesting that the Plio-Pleistocene members of subfamily Diprotodontinae may have been better adapted to moving longer distances over hard substrates (such as those in Central Australia) than the wide-gaited members of subfamily Zygomaturinae.

\section{ACKNOWLEDGMENTS}

We wish to thank the many people who helped with this project. Richard and Vivien Tedford, Ian Smith, Bob and Sue Tulloch,
Chris von der Borch, Cate Burke and David and Erica Woodgate helped with the field work. Trevor Worthy helped with the field work, photographing and measuring of trackways and critiqued the manuscript. Mike Lee helped in critiquing the manuscript. National Geographic funded the expedition into central Australia (grant number 7031-01 to Tedford and Wells). Carey Burke cast the footprint and prepared the articulated leg and hind foot from Camel Swamp Yard. Craig Reid provided measurements of the Z. trilobus specimen housed at the QVMAG.

\section{REFERENCES}

Alexander, R. M. 1976. Estimates of speeds of dinosaurs. Nature 261:129-130.

Allen, J. R. L. 1997. Subfossil mammalian tracks (Flandrian) in the Severn Estuary, S. W. Britain: mechanics of formation, preservation and distribution. Philosophical Transactions of the Royal Society of London B 352:481-518.

Ataabadi, M. M., and W. A. S. Sarjeant. 2000. Eocene mammal footprints from eastern Iran: a preliminary study. Comptes Rendus de l'Académie des Sciences - Series IIA - Earth and Planetary Science 331: 543-547.

Belperio, A. P., and D. G. Fotheringham. 1990. Geological setting of two Quaternary footprint sites, western South Australia. Australian Journal of Earth Sciences 37:37-42.

Cohen, A. S., J. Halfpenny, M. G. Lockley, and E. Michel. 1993. Modern vertebrate tracks from Lake Manyara, Tanzania and their paleobiological implications. Paleobiology 19:433-458.

Day, J. J., P. Upchurch, D. B. Norman, A. S. Gale, and H.P. Powell. 2002. Sauropod trackways, evolution and behavior. Science 296:1659.

De Vis, C. W. 1887. Anonymous. In The Brisbane Courier, 9224:6.

Hildebrand, M. 1988. Analysis of vertebrate structure. 3rd Edition. Wiley, New York.

Hutchinson, J. R., D. Famini, R. Lair, and R. Kram. 2003. Are fast moving elephants really running? Nature 422:493-494.

Laporte, L. F., and A. K. Behrensmeyer. 1980. Tracks and substrate reworking by terrestrial vertebrates in Quaternary sediments of Kenya. Journal of Sedimentary Petrology 50:1337-1346.

Lea, P. D. 1996. Vertebrate tracks in Pleistocene eolian sand-sheet deposits of Alaska. Quaternary Research 45:226-240.

Leakey, M. D. and Hay, R. L. 1979. Pliocene footprints in the Laetolil Beds at Laetoli, northern Tanzania. Nature 278:317-323.

Lockley, M. G. 1986. The paleobiological and paleoenvironmental importance of dinosaur footprints. Palaios 1:37-47.

Lockley, M. G. 1998. The vertebrate track record. Nature 396:429-432.

Lockley, M. G. B. D. Ritts, and G. Leonardi. 1999. Mammal track assemblages from the early Tertiary of China, Peru, Europe and North America. Palaios 14:398-404.

Lockley, M. G., A. S. Schulp, C. A. Meyer, G. Leonardi, and G. Kerumba Mamani. 2002. Titanosaurid trackways from the Upper Cretaceous of Bolivia: evidence for large manus, wide-gauge locomotion and gregarious behaviour. Cretaceous Research 23: $383-400$.

Long, J. A., and B. Mackness. 1994. Studies of the late Cainozoic diprotodontid marsupials of Australia. 4. The Bacchus Marsh diprotodons-geology, sedimentology and taphonomy. Records of the South Australian Museum 27:95-110.

Long, J. A., M. Archer, T. F. Flannery, and S. Hand. 2002. Prehistoric Mammals of Australia and New Guinea, One Hundred Million Years of Evolution. University of NSW Press, Sydney, 244 pp.

Mustoe, G. E. 2002. Eocene bird, reptile and mammal tracks from the Chuckanut Formation, northwest Washington. Palaios 17:403-413.

Owen, R. 1838. Fossil remains from the Wellington Valley, Australia. Appendix; pp. 359-369 in T. L Mitchell. Three Expeditions into the Interior of Eastern Australia, with Descriptions of the Recently Explored Region of Australia Felix, and of the present colony of New South Wales, T. and W. Boone, London, 2.

Pledge, N. S. and R. H. Tedford. 1990. 17:Vertebrate fossils; pp. 199-209, in J. Tyler, C.R. Twidale, M. Davies, and C.B. Wells (eds.), Natural History of the North East Deserts. Royal Society of South Australia, Adelaide.

Scott, H. H. 1915. A monograph of Nototherium tasmanicum. Tasmania Department of Mines, Geological Survey Record 4:1-47. 
Stossel, I. 1995. The discovery of a new Devonian tetrapod trackway in SW Ireland. Journal of the Geological Society of London 152:407-413

Tedford, R. H. 1973. The diprotodons of Lake Callabonna. Australian Natural History 17:349-354.

Tedford, R. H., D. L. G. Williams, and R.T. Wells. 1986. Late Cainozoic Sediments and Fossil Vertebrates; pp. 42-72, in R. T. Wells and R.A. Callen (eds.), The Lake Eyre Basin-Cainozoic Sediments, Fossil Vertebrates and Plants, Landforms, Silcretes and Climatic Implications. Australasian Sedimentologists Group, Geological Society of South Australia, Adelaide. Field Guide Series no. 4.

Tedford, R. H., and R.T. Wells. 1990. Pleistocene deposits and fossil vertebrates from the "Dead Heart of Australia". Memoirs of the Queensland Museum 28:263-284.

Tedford, R. H., R. T. Wells, and S. F. Barghoorn. 1992. Tirari Formation and contained faunas, Pliocene of the Lake Eyre Basin, South Australia. The Beagle, Records of the Northern Territory Museum of Arts and Sciences 9:173-194.
Tedford, R. H., R. T. Wells, and G. J. Prideaux. 2006. Pliocene and earlier Pleistocene marsupial evolution in southeastern Australia. Alcheringa 31 (1, special):313-322.

Thulborn, R. A. 1990. Dinosaur Tracks. Chapman and Hall, Melbourne. Thulborn, R. A. and M. Wade. 1984. Dinosaur trackways in the Winton Formation (mid-Cretaceous) of Queensland. Memoirs of the Queensland Museum 21:413-517.

Warren, J. W., and N. A. Wakefield. 1972. Trackways of tetrapod vertebrates from the Upper Devonian of Victoria, Australia. Nature 238:469-470

Webb, S., M. L. Cupper, and R. Robins. 2006. Pleistocene human footprints from the Willandra Lakes, southeastern Australia. Journal of Human Evolution 50:405-413.

Wells, R. T., and R.H. Tedford. 1995. Sthenurus (Macropodidae: Marsupialia) from the Pleistocene of Lake Callabonna, South Australia. Bulletin of the American Museum of Natural History 225:1-111.

Submitted October 1, 2007; accepted November 20, 2008. 